\title{
A meta-analysis of soil biodiversity impacts on the carbon cycle
}

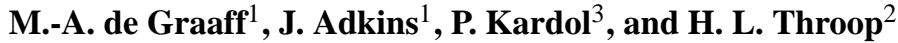 \\ ${ }^{1}$ Department of Biological Sciences, Boise State University, Boise, ID 83725, USA \\ ${ }^{2}$ Department of Biology, New Mexico State University, Las Cruces, NM 88003, USA \\ ${ }^{3}$ Department of Forest Ecol. Manag., Swedish University of Agricultural Sciences, 90183 Umeå, Sweden
}

Correspondence to: M.-A. de Graaff (marie-annedegraaff@ boisestate.edu)

Received: 25 August 2014 - Published in SOIL Discuss.: 25 November 2014

Revised: - - Accepted: 18 February 2015 - Published: 16 March 2015

\begin{abstract}
Loss of biodiversity impacts ecosystem functions, such as carbon (C) cycling. Soils are the largest terrestrial $\mathrm{C}$ reservoir, containing more $\mathrm{C}$ globally than the biotic and atmospheric pools together. As such, soil $\mathrm{C}$ cycling, and the processes controlling it, has the potential to affect atmospheric $\mathrm{CO}_{2}$ concentrations and subsequent climate change. Despite the growing evidence of links between plant diversity and soil C cycling, there is a dearth of information on whether similar relationships exist between soil biodiversity and $\mathrm{C}$ cycling. This knowledge gap occurs even though there has been increased recognition that soil communities display high levels of both taxonomic and functional diversity and are key drivers of fluxes of $\mathrm{C}$ between the atmosphere and terrestrial ecosystems. Here, we used meta-analysis and regression analysis to quantitatively assess how soil biodiversity affects soil $\mathrm{C}$ cycling pools and processes (i.e., soil $\mathrm{C}$ respiration, litter decomposition, and plant biomass). We compared the response of process variables to changes in diversity both within and across groups of soil organisms that differed in body size, a grouping that typically correlates with ecological function. When studies that manipulated both within- and across-body size group diversity were included in the meta-analysis, loss of diversity significantly reduced soil C respiration $(-27.5 \%)$ and plant tissue decomposition $(-18 \%)$ but did not affect above- or belowground plant biomass. The loss of within-group diversity significantly reduced soil C respiration, while loss of across-group diversity did not. Decomposition was negatively affected both by loss of within-group and across-group diversity. Furthermore, loss of microbial diversity strongly reduced soil $\mathrm{C}$ respiration $(-41 \%)$. In contrast, plant tissue decomposition was negatively affected by loss of soil faunal diversity but was unaffected by loss of microbial diversity. Taken together, our findings show that loss of soil biodiversity strongly impacts on soil $\mathrm{C}$ cycling processes, and highlight the importance of diversity across groups of organisms (e.g., primary consumers and secondary decomposers) for maintaining full functionality of $\mathrm{C}$ cycle processes. However, our understanding of the complex relationships between soil biodiversity and $\mathrm{C}$ cycling processes is currently limited by the sheer number of methodological concerns associated with these studies, which can greatly overestimate or underestimate the impact of soil biodiversity on soil $\mathrm{C}$ cycling, challenging extrapolation to natural field settings. Future studies should attempt to further elucidate the relative importance of taxonomic diversity (species numbers) versus functional diversity.
\end{abstract}




\section{Introduction}

Reductions in biodiversity have been linked with anthropogenic global change drivers such as climatic change, land cover change, reduction and fragmentation of natural areas, and human dependence on synthetic fertilizers (Vitousek and Mooney, 1997; Sanderson et al., 2002; Stevens, 2004; Phoenix et al., 2006; Fischer and Lindenmayer, 2007; Clark and Tilman, 2008). Over the past few hundred years, human activities have driven the species extinction rate to ca. 1000 times the typical background extinction rate (MEA, 2006). This global decline in biodiversity impacts important ecosystem functions, such as net primary production (NPP) and biogeochemical cycles of carbon $(\mathrm{C})$ and nutrients, threatening the services that ecosystems provide to the human population (Wardle et al., 2011; Cardinale et al., 2012).

The $\mathrm{C}$ cycle is a particularly important ecosystem service because the dynamic balance between $\mathrm{C}$ stored in ecosystems and in the atmosphere plays a key regulatory role in the global climate. Although vegetation stores a significant amount of $\mathrm{C}$, soils are the largest terrestrial $\mathrm{C}$ reservoir, containing more $\mathrm{C}$ globally than the biotic and atmospheric pools combined (Lal, 2004). As such, soil C dynamics, and the processes that influence them, have the potential to impact atmospheric carbon dioxide $\left(\mathrm{CO}_{2}\right)$ concentrations and subsequent global change. Perturbations in terrestrial ecosystems that influence soil $\mathrm{C}$ dynamics could help mitigate the current rise in atmospheric $\mathrm{CO}_{2}$ and associated climate change by promoting soil C storage (e.g., Cramer et al., 2001; Johnson and Curtis, 2001). Alternatively, they could exacerbate climate change by causing increased soil $\mathrm{CO}_{2}$ efflux rates through increased decomposition rates of soil organic C (SOC) (e.g., Mack et al., 2004; Bardgett et al., 2008).

Loss of biodiversity has the potential to influence climate change if it alters $\mathrm{SOC}$ pools by reducing ecosystem $\mathrm{C}$ uptake or by increasing $\mathrm{CO}_{2}$ outputs from terrestrial ecosystems to the atmosphere (Jastrow et al., 2007). Greater plant species diversity can increase $\mathrm{C}$ uptake by promoting biomass production (Tilman et al., 2006; Cardinale et al., 2012), which can enhance SOC storage (Fornara and Tilman, 2008; Steinbeiss et al., 2008; Cong et al., 2014). Conversely, declines in plant species diversity can reduce SOC storage (Hooper et al., 2012). Despite the growing body of evidence suggesting strong links between plant species diversity and soil C cycling, there is a dearth of information on whether similar relationships exist between biodiversity of soil organisms (hereafter "soil biodiversity") and C cycling (Nielsen et al., 2011). With ongoing losses in diversity belowground (Hooper et al., 2000), understanding relationships between soil biodiversity and $\mathrm{C}$ cycling is critical for projecting how loss of diversity under continued human alteration of the environment will impact global $\mathrm{C}$ cycling processes.

Soil communities typically have high levels of both taxonomic and functional diversity (e.g., De Deyn and Van der Putten, 2005). High taxonomic diversity, small sizes of or- ganisms, and large population sizes make characterization of soil communities much less straightforward than that of plant communities. As such, characterization of soil organisms is often based on body size (e.g., Bradford et al., 2002), grouping organisms into macrofauna $(>2 \mathrm{~mm})$ such as earthworms, mesofauna $\left(100 \mu \mathrm{m}^{-2} \mathrm{~mm}\right)$ such as mites and springtails, microfauna $(<100 \mu \mathrm{m})$ such as nematodes and protozoa, and soil microorganisms including bacteria and saprophytic and mycorrhizal fungi. These body size classes typically are useful functional groupings as they correlate with metrics such as metabolic rate, generation time, and food size (Peters, 1983). Estimates suggest that $1 \mathrm{~g}$ of soil can harbor tens of thousands of bacterial taxa; up to $200 \mathrm{~m}$ of fungal hyphae; and a wide range of micro-, meso-, and macrofauna (Roesch et al., 2007; Bardgett, 2005). This complex soil community plays an important role in determining the magnitude and direction of $\mathrm{C}$ fluxes between the atmosphere and terrestrial ecosystems, controlling soil $\mathrm{C}$ mineralization and promoting plant growth by regulating soil nutrient availability (e.g., De Deyn and Van der Putten, 2005; Fitter et al., 2005; Wall et al., 2010; de Vries et al., 2013). Despite a general consensus that the soil community is integral to the global $\mathrm{C}$ cycle, the impact of soil community diversity on ecosystem function is still little understood (Nielsen et al., 2011; Briones, 2014).

The positive impact of plant species diversity on soil C cycling processes can be mirrored in the soil community, with reported positive relationships between soil biodiversity and C cycling processes (e.g., Setälä, 2002; Heemsbergen et al., 2004). However, evidence suggests that this positive relationship is not universal, as other studies have found no significant impacts of soil biodiversity on $\mathrm{C}$ cycling (e.g., Griffiths et al., 2000). Understanding the relationship between soil biodiversity and $\mathrm{C}$ cycling is thus not so much a question of "does diversity matter?" but rather "under which circumstances does soil diversity affect C cycling?". One possibility for addressing this question is to consider the role of functional similarity among taxa, because relatively small or no responses of ecosystem processes to loss or gain of soil biodiversity would be expected in the case of functional redundancy among soil organisms (Bengtsson, 1998; Andrén and Balandreau, 1999; Setälä et al., 2005).

To date, studies have assessed soil community diversity impacts on soil $\mathrm{C}$ cycling by manipulating diversity within or across multiple organismal groups (specifics of grouping criteria differ among studies, but are often taxonomic, functional, or body size groups). For example, studies have manipulated the diversity within groups of microorganisms (e.g., bacteria (Bonkowski and Roy, 2005; Griffiths et al., 2000) and mycorrhizal fungi (van der Heijden et al., 1998; Maherali and Klironomos, 2007)), soil mesofauna (e.g., microarthropods; Liiri et al., 2002), and macrofauna (Heemsbergen et al., 2004; Zimmer et al., 2005). Other studies have manipulated the diversity across groups of soil organisms that differ in body size (i.e., microbes, and micro-, meso-, or 
macrofauna) or, alternatively, have manipulated diversity of trophic or functional groups (Hedlund and Ohrn, 2000; Ladygina et al., 2010). Although different taxa within soil microbial (Cox et al., 2001; Hanson et al., 2008; Orwin et al., 2006) or faunal (Bignell and Eggleton, 2000; Milcu et al., 2008; Heemsbergen et al., 2004) groups can have unique impacts on the $\mathrm{C}$ cycle, functional redundancy among taxa would be expected to be reduced when a more complex food web of organisms is manipulated (e.g., across different size classes or feeding guilds) (Setälä, 2002). Thus, studies assessing biodiversity impacts on ecosystem processes across multiple groups of soil organisms may yield very different answers than studies that probe for biodiversity impacts within single groups.

Although our knowledge of relationships between soil biodiversity and soil $\mathrm{C}$ cycling processes has increased with expanding research emphasis in this area, a comprehensive understanding to date is hampered by a lack of quantitative synthesis of existing studies. Nielsen et al. (2011) performed the most extensive synthesis on this topic to date, with a qualitative analysis. They found that diversity is often positively correlated with ecosystem function (e.g., soil respiration), although they cautioned that negative relationships between soil biodiversity and $\mathrm{C}$ cycling may be related to experimental limitations. In particular, Nielsen et al. (2011) found that strong relationships between soil biodiversity and $\mathrm{C}$ cycling were most common under unrealistically low levels of diversity. Further, their synthesis showed that the soil community composition, rather than species richness per se, had significant impacts on $\mathrm{C}$ cycling processes. This indicates high levels of functional redundancy among soil organisms and suggests that a loss of soil biodiversity may not necessarily impact the $\mathrm{C}$ cycle.

We aimed to quantitatively assess how soil biodiversity affects soil $\mathrm{C}$ cycling pools and processes using meta-analysis. We tested the general hypothesis that soil biodiversity positively impacts the soil $\mathrm{C}$ cycle, where reductions in diversity decrease soil C pools and process rates. Further, we tested the hypothesis that biodiversity manipulations across groups of organisms with different body sizes more strongly affect $\mathrm{C}$ cycling processes than manipulations within groups, due to a higher degree of functional redundancy within than across groups (Andrén and Balandreau, 1999; Setälä, 2002). In addition, we tested whether diversity of soil microbes versus soil fauna (including micro-, meso-, and macrofauna) impacts $\mathrm{C}$ cycling differently. Finally, since "biodiversity" is a metric that differs greatly in absolute numbers for soil organisms that differ in body size, we evaluated how the relative loss of diversity (in percent) within body size groups (i.e., microbes, soil fauna) affects soil $\mathrm{C}$ cycling.

\section{Methods}

\subsection{Data compilation}

We compiled published studies that explicitly manipulated soil biodiversity and measured responses of soil $\mathrm{C}$ cycling pools and/or processes. We systematically searched ISI Web of Science using all possible combinations of one soil C search term (plant biomass, soil $\mathrm{C}$, decomposition, respiration, or NPP), one soil organism search term (microbes, bacteria, fungi, microorganism*, soil fauna, soil biota, soil organism*, microfauna, mesofauna, macrofauna, nematode*, collembola, acari, termite*, earthworm*), and the term "*diversity". We used "*” as a wildcard character such that papers using either singular or plural terms were returned. Additional relevant studies referenced in those returned by the search engines were also included in the literature compilation. While biodiversity sensu stricto includes both species richness and abundance (Magurran, 2005), we follow the recent nomenclature used in plant and soil studies and assume that the number of species present in a community represents the diversity of the community.

Each study included in our analysis presented data on one or more commonly measured biogeochemical $\mathrm{C}$ pool and/or process. Biogeochemical pool measurements were plant biomass and soil $\mathrm{C}$ pools (either total soil C, dissolved organic C (DOC), or microbial biomass). Measured biogeochemical processes were soil $\mathrm{C}$ respiration and plant tissue decomposition. The duration of manipulative experiments included in this analysis ranged from 14 days to 3 years. More studies were conducted under controlled laboratory and greenhouse conditions rather than under field conditions (37 and 8 studies, respectively). When extracting data from these studies, we took values directly from published tables or the text whenever possible. If necessary, we estimated values from graphical data with image analysis software (ImageJ, National Institutes of Health, Bethesda, MD, USA).

In total we analyzed 45 published studies, of which 8 examined the effects of soil biodiversity on total plant biomass, 10 examined effects on aboveground plant biomass, 9 examined effects on root biomass, 13 examined effects on $\mathrm{C}$ respiration, 25 examined effects on decomposition, and 3 used laboratory microcosms to examine effects on soil $\mathrm{C}$ pools (Table 1). For soil C respiration, we included data that were obtained from either laboratory or in situ incubation studies in which the substrate was soil only or soil with organic amendments other than plant tissue (e.g., glucose). Laboratory studies typically estimated potential $\mathrm{C}$ mineralization rates, using temperature and moisture conditions assumed to be optimal for microbial activity. These measurements were made in closed microcosms with flux rates estimated from two or more repeated measurements of headspace gas concentrations. In situ studies used static or flow-through chambers to measure $\mathrm{CO}_{2}$ flux rates from the soil surface, and thus would include both microbial heterotrophic and root (au- 
Table 1. Overview of studies used in the analyses.

\begin{tabular}{|c|c|c|c|c|c|}
\hline $\begin{array}{l}\text { Response } \\
\text { variable }\end{array}$ & $\begin{array}{l}\text { Body size } \\
\text { group }\end{array}$ & $\begin{array}{l}\text { Size } \\
\text { class }\end{array}$ & $\begin{array}{l}\text { Taxonomic } \\
\text { group }\end{array}$ & $\begin{array}{l}\text { Number of } \\
\text { studies }\end{array}$ & Reference \\
\hline \multirow[t]{6}{*}{ Total plant biomass } & Microbes & $<5 \mu \mathrm{m}$ & Ectomycorrhizal fungi & 1 & Baxter and Dighton (2001) \\
\hline & Mesofauna & $100 \mu \mathrm{m}-2 \mathrm{~mm}$ & Microarthropods & 2 & $\begin{array}{l}\text { Liiri et al. (2002), Eisenhauer and } \\
\text { Schädler (2011) }\end{array}$ \\
\hline & Microbes + microfauna & $<5-100 \mu \mathrm{m}$ & Microflora, nematodes & 1 & Bezemer et al. (2005) \\
\hline & Microbes + macrofauna & $<5 \mu \mathrm{m},>2 \mathrm{~mm}$ & Fungi, earthworms & 2 & $\begin{array}{l}\text { Eisenhauer et al. (2010), Eisenhauer } \\
\text { and Schädler (2011) }\end{array}$ \\
\hline & Mesofauna + macrofauna & $100 \mu \mathrm{m}->2 \mathrm{~mm}$ & Collembola, enchytraeids, earthworms & 1 & Eisenhauer and Schädler (2011) \\
\hline & Microbes + microfauna + mesofauna & $<5 \mu \mathrm{m}-2 \mathrm{~mm}$ & $\begin{array}{l}\text { Bacteria, fungi, protozoa, nematodes, mi- } \\
\text { croarthropods, enchytraeids }\end{array}$ & 1 & Sulkava et al. (2001) \\
\hline \multirow[t]{7}{*}{ Shoot biomass } & Microbes & $<5 \mu \mathrm{m}$ & Ectomycorrhizal fungi & 1 & Baxter and Dighton (2001) \\
\hline & Mesofauna & $100 \mu \mathrm{m}-2 \mathrm{~mm}$ & Microarthropods & 3 & $\begin{array}{l}\text { Liiri et al. (2002), Cole et al. (2004), } \\
\text { Eisenhauer and Schädler (2011) }\end{array}$ \\
\hline & Microbes + macrofauna & $<5 \mu \mathrm{m},>2 \mathrm{~mm}$ & Fungi, earthworms & 2 & $\begin{array}{l}\text { Eisenhauer et al. (2010), Eisenhauer } \\
\text { and Schädler (2011) }\end{array}$ \\
\hline & Mesofauna + macrofauna & $100 \mu \mathrm{m}->2 \mathrm{~mm}$ & Collembola, enchytraeids, earthworms & 1 & Eisenhauer and Schädler (2011) \\
\hline & Microbes + microfauna + mesofauna & $<5 \mu \mathrm{m}-2 \mathrm{~mm}$ & $\begin{array}{l}\text { Bacteria, fungi, protozoa, nematodes, mi- } \\
\text { croarthropods, enchytraeids }\end{array}$ & 1 & Sulkava et al. (2001) \\
\hline & Microbes + microfauna + mesofauna & $<5 \mu \mathrm{m}-2 \mathrm{~mm}$ & $\begin{array}{l}\text { Bacteria, fungi, protozoa, microarthropods, } \\
\text { enchytraeids }\end{array}$ & 1 & Laakso and Setälä (1999) \\
\hline & $\begin{array}{l}\text { Microbes }+ \text { microfauna }+ \text { mesofauna } \\
+ \text { macrofauna }\end{array}$ & $5 \mu \mathrm{m}->2 \mathrm{~mm}$ & $\begin{array}{l}\text { Fungi, nematodes, enchytraeids, microarthro- } \\
\text { pods, wireworms }\end{array}$ & 1 & Ladygina et al. (2010) \\
\hline \multirow[t]{6}{*}{ Root biomass } & Microbes & $<5 \mu \mathrm{m}$ & Ectomycorrhizal fungi & 1 & Baxter and Dighton (2001) \\
\hline & Mesofauna & $100 \mu \mathrm{m}-2 \mathrm{~mm}$ & Microarthropods & 3 & $\begin{array}{l}\text { Liiri et al. (2002), Eisenhauer et } \\
\text { al. (2011), Eisenhauer and Schädler } \\
\text { (2011) }\end{array}$ \\
\hline & Microbes + macrofauna & $<5 \mu \mathrm{m},>2 \mathrm{~mm}$ & Fungi, earthworms & 2 & $\begin{array}{l}\text { Eisenhauer et al. (2010), Eisenhauer } \\
\text { and Schädler (2011) }\end{array}$ \\
\hline & Mesofauna + macrofauna & $100 \mu \mathrm{m}->2 \mathrm{~mm}$ & Collembola, enchytraeids, earthworms & 1 & Eisenhauer and Schädler (2011) \\
\hline & Microbes + microfauna + mesofauna & $<5 \mu \mathrm{m}-2 \mathrm{~mm}$ & $\begin{array}{l}\text { Bacteria, fungi, protozoa, nematodes, mi- } \\
\text { croarthropods, enchytraeids }\end{array}$ & 1 & Sulkava et al. (2001) \\
\hline & $\begin{array}{l}\text { Microbes }+ \text { microfauna }+ \text { mesofauna } \\
+ \text { macrofauna }\end{array}$ & $5 \mu \mathrm{m}->2 \mathrm{~mm}$ & $\begin{array}{l}\text { Fungi, nematodes, enchytraeids, microarthro- } \\
\text { pods, wireworms }\end{array}$ & 1 & Ladygina et al. (2010) \\
\hline \multirow[t]{7}{*}{ Respiration } & Microbes & $<5 \mu \mathrm{m}$ & Bacteria & 1 & Wertz et al. (2006) \\
\hline & Microbes & $<5 \mu \mathrm{m}$ & Bacteria, fungi & 3 & Griffiths et al. $(2000,2001,2004)$ \\
\hline & Microbes & $<5 \mu \mathrm{m}$ & Fungi & 5 & $\begin{array}{l}\text { Wilkinson et al. (2010, 2011, 2012), } \\
\text { Tiunov and Scheu (2005), Setälä and } \\
\text { McLean (2004) }\end{array}$ \\
\hline & Macrofauna & $>2 \mathrm{~mm}$ & Earthworms & 1 & Scheu et al. (2002) \\
\hline & Microbes + mesofauna & $<5 \mu \mathrm{m}, 100 \mu \mathrm{m}-2 \mathrm{~mm}$ & Microflora, enchytraeids, microarthropods & 1 & Edsberg (2000) \\
\hline & Mesofauna + macrofauna & $100 \mu \mathrm{m}->2 \mathrm{~mm}$ & Not specified & 1 & Risch et al. (2013) \\
\hline & $\begin{array}{l}\text { Microfauna }+ \text { mesofauna }+ \text { macro- } \\
\text { fauna }\end{array}$ & $5 \mu \mathrm{m}->2 \mathrm{~mm}$ & Nematodes, enchytraeids, earthworms & 1 & Bradford et al. (2007) \\
\hline \multirow[t]{18}{*}{ Decomposition } & Microbes & $<5 \mu \mathrm{m}$ & Bacteria & 1 & Bell et al. (2005) \\
\hline & Microbes & $<5 \mu \mathrm{m}$ & Fungi & 3 & $\begin{array}{l}\text { Progar et al. (2000), Toljander et } \\
\text { al. (2006), LeBauer et al. (2010) }\end{array}$ \\
\hline & Microbes & $<5 \mu \mathrm{m}$ & Bacteria, fungi & 3 & $\begin{array}{l}\text { Griffiths et al. (2000, 2001), Liebich et } \\
\text { al. (2007) }\end{array}$ \\
\hline & Mesofauna & $100 \mu \mathrm{m}-2 \mathrm{~mm}$ & Collembola & 2 & $\begin{array}{l}\text { Cragg and Bardgett (2001), Eisenhauer } \\
\text { and Schädler (2011) }\end{array}$ \\
\hline & Macrofauna & $>2 \mathrm{~mm}$ & Woodlice, millipedes & 1 & Collison et al. (2013) \\
\hline & Macrofauna & $>2 \mathrm{~mm}$ & Woodlice, earthworms & 1 & Zimmer et al. (2005) \\
\hline & Microbes + microfauna & $<5 \mu \mathrm{m}-100 \mu \mathrm{m}$ & Bacteria, fungi, nematodes & 2 & Mikola and Setälä $(1998 a, b)$ \\
\hline & Microbes + mesofauna & $<5 \mu \mathrm{m}, 100 \mu \mathrm{m}-2 \mathrm{~mm}$ & Microflora, enchytraeids, microarthropods & 1 & Edsberg (2000) \\
\hline & Microbes + mesofauna & $<5 \mu \mathrm{m}, 100 \mu \mathrm{m}-2 \mathrm{~mm}$ & Fungi, collembola, mites & 1 & Hedlund and Ohrn (2000) \\
\hline & Microbes + macrofauna & $<5 \mu \mathrm{m},>2 \mathrm{~mm}$ & Fungi, ants, termites & 1 & Warren and Bradford (2012) \\
\hline & Microbes + microfauna + mesofauna & $<5 \mu \mathrm{m}-2 \mathrm{~mm}$ & $\begin{array}{l}\text { Bacteria, fungi, protozoa, nematodes, mi- } \\
\text { croarthropods, enchytraeids }\end{array}$ & 1 & Sulkava et al. (2001) \\
\hline & Microbes + microfauna + mesofauna & $<5 \mu \mathrm{m}-2 \mathrm{~mm}$ & $\begin{array}{l}\text { Bacteria, fungi, nematodes, protozoa, collem- } \\
\text { bola, enchytraeids, mites }\end{array}$ & 1 & Cortet et al. (2003) \\
\hline & Microbes + microfauna + mesofauna & $<5 \mu \mathrm{m}-2 \mathrm{~mm}$ & Not specified & 2 & $\begin{array}{l}\text { Heneghan et al. (1999), Wall et } \\
\text { al. (2008) }\end{array}$ \\
\hline & $\begin{array}{l}\text { Microfauna }+ \text { mesofauna }+ \text { macro- } \\
\text { fauna }\end{array}$ & $5 \mu \mathrm{m}->2 \mathrm{~mm}$ & $\begin{array}{l}\text { Protozoa, nematodes, enchytraeids, arthropods, } \\
\text { earthworms }\end{array}$ & 1 & Bradford et al. (2002) \\
\hline & $\begin{array}{l}\text { Microbes }+ \text { microfauna }+ \text { mesofauna } \\
+ \text { macrofauna }\end{array}$ & $<5 \mu \mathrm{m}->2 \mathrm{~mm}$ & Fungi, arthropods & 1 & Araujo et al. (2012) \\
\hline & $\begin{array}{l}\text { Microbes }+ \text { microfauna }+ \text { mesofauna } \\
+ \text { macrofauna }\end{array}$ & $5 \mu \mathrm{m}->2 \mathrm{~mm}$ & $\begin{array}{l}\text { Fungi, bacteria, protozoa, nematodes, mi- } \\
\text { croarthropods }\end{array}$ & 1 & Carrillo et al. (2011) \\
\hline & $\begin{array}{l}\text { Microbes }+ \text { microfauna }+ \text { mesofauna } \\
+ \text { macrofauna }\end{array}$ & $<5 \mu \mathrm{m}->2 \mathrm{~mm}$ & Not specified & 1 & Slade and Riutta (2012) \\
\hline & $\begin{array}{l}\text { Microbes }+ \text { microfauna }+ \text { mesofauna } \\
+ \text { macrofauna }\end{array}$ & $<5 \mu \mathrm{m}->2 \mathrm{~mm}$ & Not specified & 1 & Yang and Chen (2009) \\
\hline \multirow[t]{3}{*}{ Soil C } & Microbes & $<5 \mu \mathrm{m}$ & Bacteria, fungi & 1 & Liebich et al. (2007) \\
\hline & Mesofauna & $100 \mu \mathrm{m}-2 \mathrm{~mm}$ & Collembola & 1 & Cragg and Bardgett (2001) \\
\hline & Macrofauna & $>2 \mathrm{~mm}$ & Woodlice, earthworms & 1 & Zimmer et al. (2005) \\
\hline
\end{tabular}


totrophic) respiration (Holland et al., 1999). Plant tissue decomposition data were obtained from studies that measured either litter mass loss through time or $\mathrm{C}$ respiration from plant tissues decomposed under controlled laboratory conditions. Litter mass loss analyses used mesh litterbags and measured mass at two or more points in time (Harmon et al., 1999). For studies in which the source of decomposed material (i.e., soil or plant C) could be partitioned, data were separated and included in soil $\mathrm{C}$ respiration or plant tissue decomposition data groupings. For all biogeochemical pool and process studies in which data were available from multiple measurement times, we calculated the mean value for all measurement times and used only that value in the metaanalysis.

Soil biodiversity impacts on $\mathrm{C}$ respiration and decomposition were assessed by manipulating biodiversity either within a single body size group (i.e., microbes (including bacteria and fungi), micro-, or meso-, or macrofauna) or across multiple body size groups (e.g., micro-, meso-, macrofauna; e.g., Bradford et al., 2002). We treated the within-body size and across-body size groupings as two separate categories for the analysis. For plant biomass, however, there were not enough studies to run meta-analyses for individual categories. We also categorized the studies by soil microorganisms or soil fauna (micro-, meso-, and macro fauna grouped together due to inadequate numbers of studies to split these up). Categorizing studies in this manner allowed us to assess whether species diversity within or across body size groups affected $\mathrm{C}$ cycling differently, while also enabling us to compare the relative impacts of diversity within the soil microbial community versus soil biodiversity within the soil faunal community.

Many of the studies we compiled assessed soil biodiversity impacts on $\mathrm{C}$ cycling by quantifying responses to a diversity gradient (e.g., $>2$ diversity levels). Inherent to this design is the possibility for multiple comparisons among diversity treatments. For example, an analysis of how diversity of a three species community (species $a, b$, and $c$ ) affects ecosystem processes could yield a comparison of each single-species community $(a, b$, or $c$ ) with the three-species community $(a+b+c)$. This comparison yields three observations: (1) " $a$ " versus " $a+b+c$ ", (2) " $b$ " versus " $a+b+c$ ", and (3) "c" versus " $a+b+c$ ". In our meta-analysis we did not consider these three comparisons to be independent, but we calculated the mean of the three single-species treatments and then calculated one response variable based on the comparison between that one single-species mean and the threespecies community. Intermediate levels of diversity were excluded from the meta-analysis to avoid any individual study from unduly weighting the analysis. This method prevented studies with a large species diversity gradient (i.e., a multitude of species included in the analysis) from dominating our meta-analysis.

\subsection{Statistical analyses}

To test how soil microbial and/or soil faunal diversity affects ecosystem C pools (plant biomass) and processes (C respiration and decomposition), and to test whether biodiversity manipulations across multiple body size groups affected $\mathrm{C}$ cycling differently from manipulations within groups, we analyzed the data set with meta-analysis (Curtis and Wang, 1998; Hungate et al., 2009), using the statistical software MetaWin 2.0 (Rosenberg et al., 2000). We were unable to use meta-analysis for soil $\mathrm{C}$ pools because the number of studies available (3) was inadequate for a meaningful analysis. The response ratio $(R)$ was calculated as the value of a particular response variable at low diversity divided by the value at high diversity. The natural log of the response ratio $R(\ln R)$ was used as a metric for all of the response variables (de Graaff et al., 2006; van Groenigen et al., 2006). To ease interpretation of figures, the results for the analyses on $\ln R$ were back-transformed to response ratios and reported as percentage change under a reduction in diversity (that is, $100 \times[R-1]$ ). Thus, for response variables where there was no change between higher and lower diversity communities, the change would equal 0 . For cases with greater values for response variables in low-diversity communities than high-diversity communities, the percent change would be would be positive, and lower values for response variables in low-diversity communities than high-diversity communities would yield negative values for the percent change.

Conventional meta-analyses weight each individual observation by the reciprocal of the mixed model variance (Curtis and Wang, 1998). However, such an analysis requires that the standard deviations of individual studies be known. These data were not available for a large proportion of the studies used in our analysis. Thus, we weighted individual values included in the analysis by experimental replication (Hedges and Olkin, 1985; Adams et al., 1997), assuming that betterreplicated experiments resulted in data with lower variance. We choose this metric because well-replicated studies provide more reliable estimates of the response of individual variables (e.g., Hungate et al., 1996, 2009). We used bootstrapping to calculate confidence intervals on mean effect size estimates for the whole data set and for individual categories (Adams et al., 1997). We considered diversity effects significant if the $95 \%$ confidence intervals did not overlap with zero. In addition, we considered diversity effects for individual categories different from each other if they varied significantly at the $p \leq 0.05$ level.

Further, we tested how a loss of belowground species diversity is linked to changes in $\mathrm{C}$ pools and processes by performing linear regressions with percent change in species diversity and the effect size $(\ln R)$ of each of the response variables. Percent change in diversity was calculated as (low diversity - high diversity/high diversity) $\times 100$. Since the absolute number of species typically manipulated for diversity gradient studies varies among species that differ in body size 


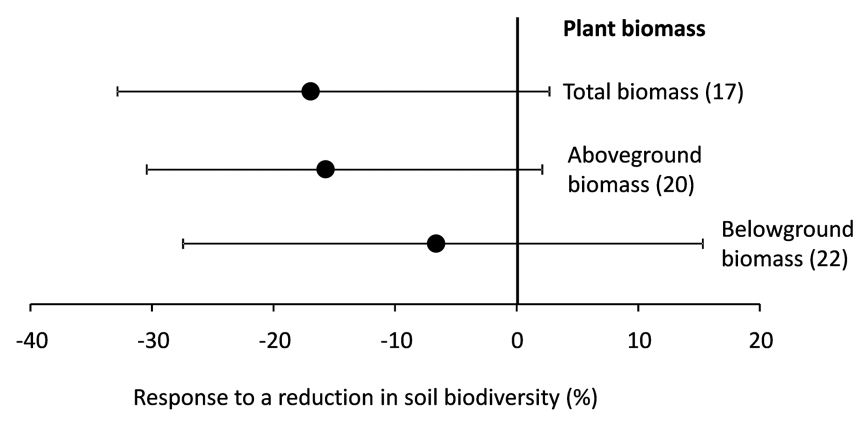

Figure 1. The percent response of total plant biomass, shoot biomass, and root biomass to a change in soil community diversity (i.e., "high" vs. "low" diversity). Studies included in the analysis manipulated diversity of the soil microbial community, the soil micro-, meso, or macrofaunal community or a combination of these trophic groups. Data represent means with $95 \%$ confidence intervals; numbers in brackets represent the total number of data points included in the analysis.

in absolute terms (i.e., many more species are usually present in studies of microbial diversity than in studies of faunal diversity), we calculated relative differences in species diversity for each treatment. Thus manipulation of microbial diversity might include a low-diversity treatment of 100 versus a high-diversity treatment of 1000 species, while manipulation of soil fauna might span from low diversity of 1 species to high diversity of 10 species. Calculated as relative differences in diversity, both examples would be the same (i.e., low diversity is $10 \%$ of the number of species present in high diversity). We performed two sets of regressions. The first included all soil biodiversity levels, and the second included the highest and lowest biodiversity levels only. We used linear regression (SPSS v. 20) to regress $\ln R$ against relative change in species diversity. We performed regressions in which we considered $\ln R$ (the effect size) between every diversity level, and also regressions in which we only considered $\ln R$ between the highest and lowest diversity levels, omitting intermediate diversity levels.

\section{Results}

\subsection{Impacts of soil biodiversity on ecosystem C pools and processes}

Results from our meta-analyses indicate very different responses to changes in soil biodiversity among $\mathrm{C}$ pools (plant biomass; soil $\mathrm{C}$ pools not included because of inadequate number of studies) and processes (soil $\mathrm{C}$ respiration and plant tissue decomposition). Plant biomass did not respond to changes in diversity, either when analyzed as total biomass or partitioned into aboveground and belowground biomass (Fig. 1). In contrast to the lack of impact on plant $\mathrm{C}$ pools, decreased soil biodiversity (including studies that manipulated diversity within and across body size groups) corresponded

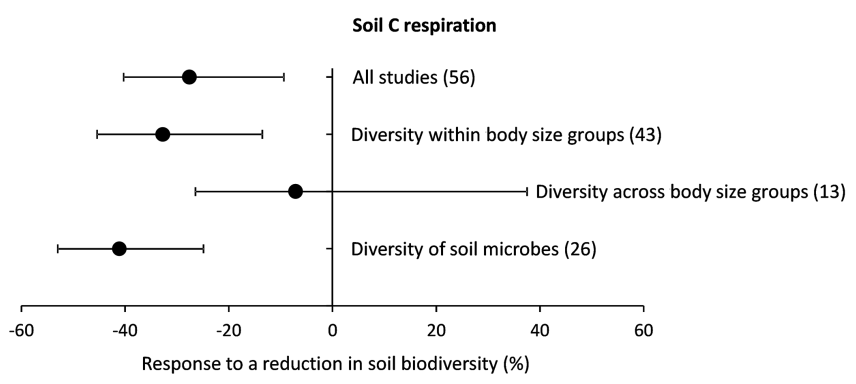

Figure 2. The percent response of soil $\mathrm{C}$ respiration to a change in soil community diversity (i.e., "high" vs. "low" diversity). Studies included in the analysis manipulated diversity of the soil microbial community; the soil micro-, meso, or macrofaunal community; or a combination of these body size groups ("all studies"). Further studies are categorized by studies that manipulated species diversity within or across body size groups, and by studies that manipulated the soil microbial community (including fungi and bacteria) or the soil faunal community (including micro-, meso-, and macrofauna). Data represent means with $95 \%$ confidence intervals; numbers in brackets represent the total number of data points included in the analysis.

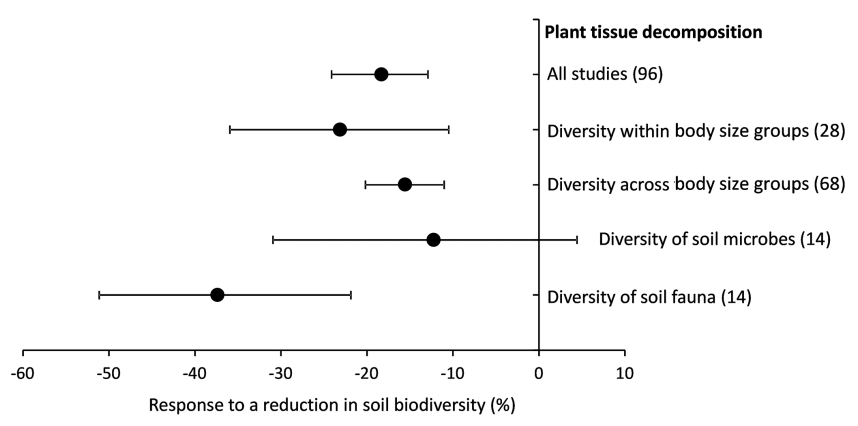

Figure 3. The percent response of decomposition to a change in soil community diversity (i.e., "high" vs. "low" diversity). Studies included in the analysis manipulated diversity of the soil microbial community; the soil micro-, meso, or macrofaunal community; or a combination of these trophic groups ("all studies"). Further studies are categorized by studies that manipulated species diversity within or across body size groups, and by studies that manipulated the soil microbial community (including fungi and bacteria) or the soil faunal community (including micro-, meso-, and macrofauna). Data represent means with $95 \%$ confidence intervals; numbers in brackets represent the total number of data points included in the analysis.

to a mean $27.5 \%$ reduction in soil $\mathrm{C}$ respiration (Fig. 2) and a mean $18 \%$ reduction in decomposition (Fig. 3 ).

When soil $\mathrm{C}$ respiration responses were partitioned into studies that manipulated diversity within body size groups versus those that manipulated diversity across body size groups, we found a significant effect only for within-group manipulations (Fig. 2). Due to a lack of studies that manipulated solely soil fauna (there was just one study: Scheu et al., 2002), we were unable to compare how a change in soil faunal biodiversity versus soil microbial biodiversity impacts 
soil C respiration. However, when we omitted studies manipulating soil faunal biodiversity from our analysis and assessed impacts of reductions in soil microbial biodiversity alone on soil $\mathrm{C}$ respiration, we found that soil $\mathrm{C}$ respiration was reduced by $41 \%$ (Fig. 2).

Plant tissue decomposition generally responded negatively to reductions in soil biodiversity (Fig. 3). Studies that manipulated diversity within soil organismal groups and those that manipulated diversity across organismal groups both led to similar reductions in decomposition (means of $23 \%$ and $15 \%$, respectively; Fig. 3). Further, whereas reduced soil microbial diversity did not significantly reduce decomposition rates, reduced soil faunal diversity led to a $37 \%$ reduction in mean decomposition (Fig. 3).

\subsection{Relationships between diversity loss and C cycling processes}

Regression analyses revealed a negative linear relationship between soil biodiversity and $\ln R$ for soil $\mathrm{C}$ respiration (Fig. 4). This relationship was significant when we regressed the percent change in soil biodiversity and $\ln R$ for $\mathrm{C}$ respiration based on all diversity treatments in the compiled studies (Fig. 4a) and also when we calculated $\ln R$ for the highest and lowest diversity treatments only (Fig. 4b). We further examined how a decline in diversity within body size groups (data available for microorganisms and macrofauna) and across body size groups (multiple body size groups) was related to soil $\mathrm{C}$ respiration. Soil microbial diversity was the only body size group significantly related to soil $\mathrm{C}$ respiration, with a decline in soil microbial diversity reducing $\mathrm{C}$ respiration (Fig. 4a). The paucity of data available for the other body size groups prevented us from running any meaningful regression analyses. We have, however, highlighted the other body size groups in the regression figure to depict the dearth of studies on these organisms relative to microbes.

Regression analysis also revealed a significant response in decomposition to altered biodiversity when all studies were included (Fig. 5a), but not when only the highest and lowest diversity treatments were included (Fig. 5b). Reductions in biodiversity did not significantly affect decomposition in studies that measured litter mass loss. Conversely, when decomposition was measured via $\mathrm{CO}_{2}$ efflux, there was a significant relationship between decomposition and biodiversity change when all diversity treatments were included in the analysis $\left(R^{2}=0.307, p<0.001\right.$; data not shown).

\section{Discussion}

Changes in biodiversity have been linked with changes in ecosystem functioning, but so far studies have largely focused on plant diversity (e.g., Isbell et al., 2011). Whether or not similar patterns exist for soil biodiversity remains largely unknown. Here, we provide the first quantitative synthesis of studies testing effects of soil biodiversity on $\mathrm{C}$ cycling. Us-

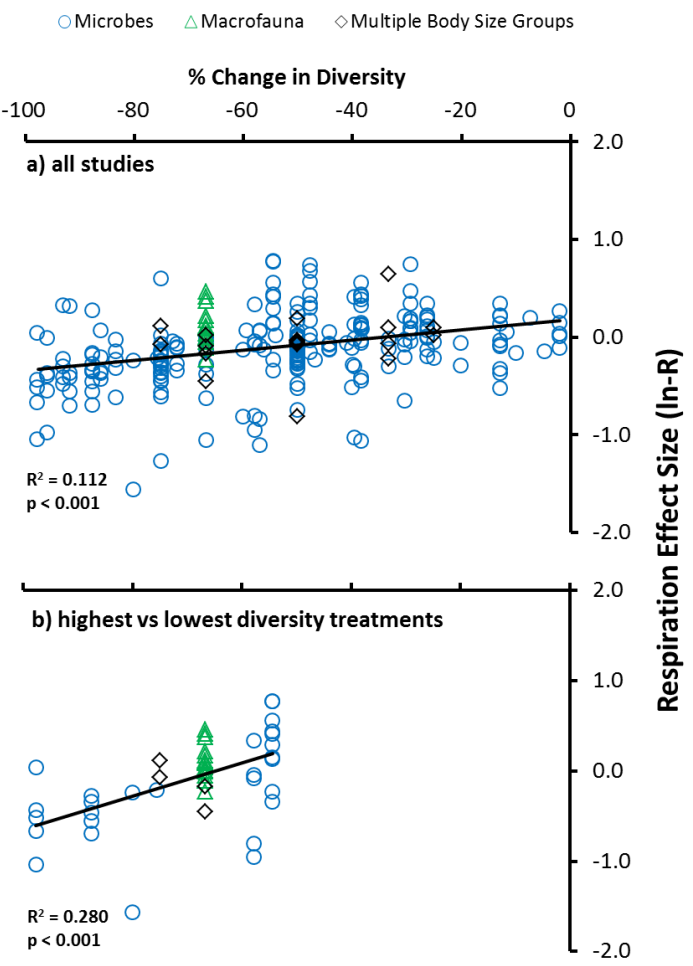

Figure 4. Regressions between a percent change in the soil microbial, soil macrofaunal, or soil microbial and soil faunal communities (i.e., multiple organismal groups) and the natural log of the response ratio of soil $\mathrm{C}$ respiration $(\ln R$; calculated as the natural $\log$ of the response ratio, $R$, which was the value of the response variable at low diversity divided by the value at high diversity). No studies in our literature compilation of soil $\mathrm{C}$ respiration included manipulation of only soil microfauna or mesofauna, so these body size groups are not included in the figure. Percent change in diversity was calculated as (low diversity - high diversity/high diversity) $\times 100$. (a) includes all possible comparisons across diversity gradients in studies, whereas (b) includes the comparisons between the lowest and highest diversity levels only.

ing meta-analysis and regression analysis, we showed that loss of soil biodiversity can have negative consequences for the soil $\mathrm{C}$ cycle but that relationships between $\mathrm{C}$ cycling processes with soil biodiversity vary across groups of soil organisms and are process-dependent. Below we explore how our findings contribute to our knowledge of how soil biodiversity drives ecosystem functions. We also discuss experimental shortcomings and methodological challenges and suggest directions for future research.

\subsection{Biodiversity impacts on $\mathrm{C}$ pools}

Few studies have assessed the relationship between soil biodiversity and soil $\mathrm{C}$ pools. We found just three studies in our literature search, and these studies all used different indices of soil C pools: ergosterol, which is a measure of fungal biomass (Liebich et al., 2007); dissolved organic C (Cragg 


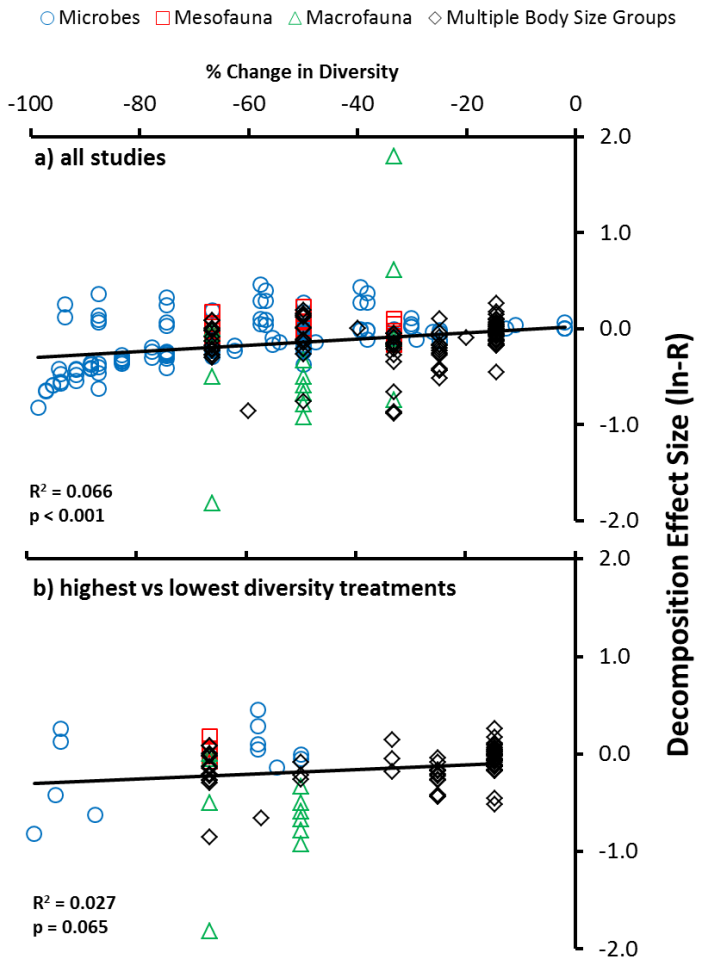

Figure 5. Regressions between a percent change in the soil microbial, mesofaunal, macrofaunal, or soil microbial and soil faunal communities (i.e., multiple organismal groups) and the natural log of the response ratio of litter decomposition $(\ln R$; calculated as the natural $\log$ of the response ratio, $R$, which was the value of the response variable at low diversity divided by the value at high diversity). No studies in our literature compilation of litter decomposition included manipulation only of soil microfauna, so this body size group is not included in the figure. Percent change in diversity was calculated as (low diversity - high diversity/high diversity) $\times 100$. (a) includes all possible comparisons across diversity gradients in studies, whereas (b) includes the comparisons between the lowest and highest diversity levels only.

and Bardgett, 2001); and soil organic C concentration (Zimmer et al., 2005). All three studies were of short duration (range: 42 to 70 days) and were conducted in microcosms in which diversity of the microbial community (Liebich et al., 2007), microfauna (collembola; Cragg and Bardgett, 2001), or macrofauna (earthworms and woodlice; Zimmer et al., 2005) was manipulated. Due to the small number of studies, we were unable to conduct a quantitative analysis. However, none of the individual studies showed an impact of soil biodiversity on soil C pools. It is probably not surprising that very few studies attempted to relate soil community diversity to soil $\mathrm{C}$ pools, due to the difficulty of maintaining soil biodiversity manipulations in microcosms for long time periods. Bulk soil organic $\mathrm{C}$ pools are typically stable on the order of years to decades due the large pool sizes and the relatively slow rates of biological processes (Conen et al., 2003; Smith, 2004), so short-term effect of soil biodiversity on this pool would be expected to be low and undetectable. We expect that some metrics of the relatively labile fraction in the soil $\mathrm{C}$ pool (e.g., particulate organic matter, DOC) will be more temporally dynamic than the bulk pool (Six et al., 2002) and would be better target response variables for assessing biodiversity impacts. Even more likely to provide information on soil biodiversity impacts on soil $\mathrm{C}$ cycling are studies assessing diversity effects on short-term $\mathrm{C}$ fluxes.

Plant biomass, assessed as a whole or partitioned into root and shoot biomass, was not significantly affected by soil biodiversity. Our analysis included studies that manipulated diversity of mycorrhizal fungi (Baxter and Dighton, 2001), microarthropods (Liiri et al., 2002), meso- and macrofaunal decomposers (Eisenhauer and Schädler, 2011), or more complex foodwebs consisting of multiple groups of different body sizes (Sulvaka et al., 2001; Laakso and Setälä, 1999; Ladygina et al., 2010; Eisenhauer et al., 2010; Eisenhauer and Schädler, 2011). The lack of a response of plant biomass production to soil biodiversity results from the contradicting results generated across a number of studies, and indicates that soil biodiversity does not unequivocally promote plant production (reviewed in van der Heijden et al., 2008). With the exception of rhizosphere organisms such as mycorrhizal fungi, rhizobia, and root pathogens or herbivores, linkages between soil organisms and plant biomass are indirect, i.e., decomposer organisms break down organic compounds and make nutrients available for plant uptake (Wardle et al., 2004). This indirect link between plant growth and soil organisms may result in a rather weak relationship between soil biodiversity and plant production (Balvanera et al., 2006). In line with this, we did find a trend of decreased plant production with loss of soil biodiversity. However, the limited number of studies reduced our statistical power, restricting our ability to quantify soil biodiversity impacts on plant biomass production. Another complication in assessing biodiversity impacts on plant production is that to date studies have exclusively been conducted in laboratory and greenhouse settings. While laboratory manipulations can provide useful information about potential controls over ecological processes, these manipulations are by necessity short-term (range: 35 days-52 weeks for the studies we compiled) and may include only a subset of the complex food webs and biogeochemical processes that occur in natural field settings (Hol et al., 2010). Furthermore, diversity effects may become more apparent over time as functional redundancy declines (Reich et al., 2012).

Although soil biodiversity did not conclusively impact soil $\mathrm{C}$ pools or affect plant biomass production, biodiversity as a whole appears to play an important role in maintaining and enhancing plant biomass production and soil C pools. For example, plant diversity can promote plant biomass production and soil C storage (Tilman et al., 2006; Cardinale et al., 2012; Fornara and Tilman, 2008; Steinbeiss et al., 2008), and these benefits of aboveground biodiversity on ecosystem functions are often attributed to increases in plant nutrient uptake re- 
sulting from belowground spatial and temporal differentiation in resource use (e.g., McKane et al., 1990; Tilman et al., 1996; Casper and Jackson, 1997; Schenk et al., 1999; van Ruijven and Berendse, 2005; van der Heijden et al., 2003). As such, a single limiting resource (e.g., soil N) may be spatially partitioned among co-occurring plant species, which reduces inter-specific competition and thereby facilitates coexistence (McKane et al., 1990). It is reasonable to expect that similar mechanisms occur for soil organisms (Prosser and Nicol, 2012; Sechi et al., 2015), and effects of plant and soil organism diversity on ecosystem functions may not be independent of each other, as increased plant diversity may be accompanied by increased soil biodiversity (Scherber et al., 2010; Eisenhauer et al., 2011a, b). If this is the case, soil biodiversity could explain, at least in part, the observed positive relationship between plant diversity and ecosystem $\mathrm{C}$ pools and processes. It is worthy of mention here that soil fungal pathogens have been found an important driver of observed positive relationships between plant diversity and productivity (Maron et al., 2011).

\subsection{Soil biodiversity impacts on soil C processes}

Results from our meta-analysis show that loss of soil biodiversity significantly reduces soil $\mathrm{C}$ respiration $(-27.5 \%)$. This is a strong reduction in soil $\mathrm{C}$ mineralization that could have important ecosystem-level consequences for the soil $\mathrm{C}$ cycle. However, some caution is warranted in interpreting these results as the experimental design of many of the studies included in the analyses may have inadvertently over- or underestimated soil biodiversity impacts on processes important to the soil C cycle (Nielsen et al., 2011). The response of $\mathrm{C}$ respiration to a loss in soil biodiversity was overwhelmingly driven by studies manipulating soil microbial diversity, and when we categorized the analysis by studies that manipulated the soil microbial community only, the average response to a reduction in biodiversity was even greater $(-41 \%)$. In addition, the regression analysis revealed that a loss in soil biodiversity was significantly related to a loss in soil $\mathrm{C}$ respiration only when soil microbial diversity was included in the analysis. This suggests that these studies contributed in large part to the strong response of soil $\mathrm{C}$ respiration to a reduction in soil biodiversity. Many of these studies used a relatively low number of microbial species when compared to soil microbial diversity in natural ecosystems. For example, Setälä and McLean (2004) used 43 taxa of saprophytic fungi, a large number relative to most manipulative experiments, but a small number relative to the estimated number of fungi in natural soils. In addition, the majority of the studies were conducted under highly controlled and shortterm laboratory conditions. Some studies used fumigation or dilution methods to alter soil microbial diversity (Griffiths et al., 2000, 2001, 2004; Wertz et al., 2006), and although it appears that microbial diversity decreases with increased dilution or fumigation, the main impacts of these treatments may be on the community structure by favoring taxa that physiologically withstand the pressures of dilution or fumigation. Studies using this technique showed that the response of $\mathrm{C}$ respiration to an increase in biodiversity leveled off (Bell et al., 2005) with increasing species number, and that responses to these treatments are often idiosyncratic, which suggests that they are driven by the soil microbial community structure rather than by diversity. Thus, although our synthesis indicates that the response of soil $\mathrm{C}$ respiration to a reduction in soil biodiversity can be significant, we contend that the response may be an overestimation of what would happen in soils with natural communities.

Although many studies have assessed the impact of soil microbial diversity on soil $\mathrm{C}$ respiration, only one study evaluated effects of soil faunal diversity (earthworms) on C respiration (Scheu et al., 2002). This study indicated that soil faunal richness impacts soil microbial community functioning, which may in turn alter soil $\mathrm{C}$ respiration. Soil fauna can strongly affect microbial processes and community composition by enhancing the availability of resources to the microbial community (Edwards, 2000; Heal et al., 1997; Petersen and Luxton, 1982). For example, invasive earthworms in North America have been associated with changes in soil respiration, although these effects may be mediated through changes in the abundance of other organisms, such as microbes (Szlavecz et al., 2011) or availability of soil and litter resources (Huang et al., 2010). Thus, a change in the diversity of soil fauna is expected to alter soil $\mathrm{C}$ respiration, but more studies that manipulate soil fauna are required to confirm this hypothesis.

Results from the meta-analysis and the regression analysis show that loss of soil biodiversity significantly reduces plant tissue decomposition $(-18 \%)$. Unlike the other response variables, soil biodiversity impacts on plant tissue decomposition were not dominated by studies that manipulated the soil microbial community. Rather, ca. $84 \%$ of decomposition studies in our compilation manipulated soil fauna or multiple groups of soil organisms; soil faunal biodiversity effects on plant tissue decomposition were significant $(-37 \%)$. The significant impact of soil faunal manipulations on litter decomposition may be due to the strong direct effect of soil fauna on litter decomposition, particularly in the early stages of decomposition (Heemsbergen et al., 2004; Berg and Laskowski, 2006; Milcu and Manning, 2011). By contrast, soil microbial diversity reductions alone did not significantly suppress decomposition rates. This finding is despite individual observations that the diversity of litter-associated microbes increases as decomposition proceeds (e.g., Dilly et al., 2004). Nonetheless, based on our observation that soil faunal diversity has a strong impact on plant tissue decomposition, we propose that diversity of the soil community, and particularly soil faunal diversity, is an important factor driving rates of litter decomposition. This notion is supported by a recent article showing that a reduction in the diversity of detritivores (both microorganisms and invertebrates) slows the rate 
at which litter is decomposed, regardless of the location of the experiment (Handa et al., 2014).

We hypothesized that diversity across multiple organismal groups composed of different body sizes would impact soil $\mathrm{C}$ cycling processes to a greater extent than diversity within groups of organisms with a single body size, with the assumption that within-group diversity would be accompanied by a greater degree of functional redundancy (Laakso and Setälä, 1999; Wardle, 1999; Cragg and Bardgett, 2001). For example, a higher diversity of feeding guilds has been linked to more effective substrate use (Setälä and Huhta, 1991). Our analysis, however, suggests that, for plant tissue decomposition, diversity across multiple body size groups has similar impacts on soil $\mathrm{C}$ cycling to diversity within body size groups. For soil $\mathrm{C}$ respiration, the effect of reduced diversity within groups was even stronger than that of smaller diversity across groups. This may result from the approaches taken to assess community impacts on soil $\mathrm{C}$ cycling. First, there is a lack of consistency in approaches taken to study effects of soil biodiversity on $\mathrm{C}$ cycling, both for the withinand the across-body size group approach. As such, the level of functional diversity between "high-" and "low-" diversity treatments may have varied across studies, and it is unclear whether shifts in functional diversity were greater for acrossgroup manipulations than for within-group manipulations. Except for Heemsbergen et al. (2004), no studies have explicitly tested for the functional dissimilarity among the species manipulated. Second, populations of soil organisms at lower trophic levels may show compensatory growth responses to loss of biomass predation by organisms of higher trophic levels (e.g., Ingham et al., 1985), resulting in no net effect of manipulation of trophic diversity on the processes regulated by lower-trophic-level soil organisms. Third, effects of functional or trophic groups of organisms may have opposing effects on the $\mathrm{C}$ cycling pools and process rates. For example, Ladygina et al. (2010) showed that arbuscular mycorrhizal fungi and decomposer (enchytraeids and collembola) canceled each other out in affecting plant community biomass.

\subsection{Methodological concerns}

While manipulating diversity of any group of organisms is fraught with challenges, manipulation of soil organism diversity is particularly challenging. A more comprehensive assessment of soil diversity impacts on $\mathrm{C}$ cycling will require that some of these challenges are addressed. Nielsen et al. (2011) found that the response to a reduction in diversity was greater if diversity levels were low (i.e., $<10$ species included in the analysis) and conducted under more controlled experimental conditions, rather than under high diversity (i.e., $>10$ species included in the analysis) and more natural experimental conditions. Our analysis set out to quantify how the design of the study affected soil $\mathrm{C}$ cycling processes, by comparing studies that manipulated soil biodiversity within a single body size group with studies that manip- ulated biodiversity across multiple groups. Across-body size group manipulations approach the natural complexity of soil food webs to a much greater degree than within-group manipulations. However, even the most complex manipulations accounted only for a fraction of the diversity likely under natural field conditions. As such, to further enhance our understanding of soil community diversity impacts on soil $\mathrm{C}$ cycling, studies should incorporate more natural conditions in their design and manipulate more complete soil communities. A recent study by Wagg et al. (2014) used a method for manipulating a broad size range of soil organisms by inoculating sterilized soils with soil communities derived through a series of different-sized filters. This method allowed the researchers to successfully obtain a broad soil biodiversity gradient within and across groups of soil organism that span a gradient in body sizes in their grassland microcosms, and showed that soil biodiversity loss and simplification of soil community composition impairs multiple ecosystem functions, including litter decomposition and soil $\mathrm{C}$ sequestration. However, filtering groups of organisms based on body size does not allow for separating between effects of functional dissimilarity from effects of biodiversity (species richness) per se. This underscores the pervasive challenge to truly measuring biodiversity effects on ecosystem processes. A parallel concern is that soil biodiversity typically cuts across multiple trophic groups (e.g., manipulation of nematodes would potentially alter both herbivores and predators in the soil). Aboveground diversity-ecosystem function studies have typically been limited to the primary producer trophic level, but results may yield very different relationships if consumer trophic levels are included in diversity manipulations (Borer et al., 2014). Finally, we caution that measuring soil biodiversity is exceedingly difficult, and in many cases treatments were assumed to affect biodiversity for the duration of the experiment, but this was often not measured. It is also possible that a change in the relative abundance of organisms is an important component of biodiversity and studies in our compilation typically equated species richness with diversity, whereas biodiversity sensu stricto includes both species richness and abundance (Magurran, 2005). To fully comprehend how biodiversity impacts ecosystem function, an attempt should be made at manipulating and maintaining different levels of soil community diversity, in the strict sense of the definition.

\section{Conclusions}

If we are to fully understand how anthropogenically induced changes in biodiversity affect the terrestrial $\mathrm{C}$ cycle, we must dig deeper and embrace the challenges associated with studying the belowground world. Understanding the complex relationships between soil biodiversity and $\mathrm{C}$ cycling processes is currently limited by the sheer number of methodological concerns associated with these studies, which can greatly 
overestimate or underestimate the impact of soil biodiversity on soil $\mathrm{C}$ cycling, challenging extrapolation to natural field conditions. Nonetheless, our data point towards a definite importance of soil community diversity on key $\mathrm{C}$ cycling processes. Our quantitative analysis revealed significant negative effects of loss of soil biodiversity on rates of soil respiration and litter decomposition. If this is the case, declines in soil biodiversity could significantly affect the rates and dynamics of $\mathrm{C}$ cycling. However, biodiversity effects were not always consistent across groups of organisms. Differential responses of groups of organisms could be related to their functional role in the respective processes. It is, however, important to emphasize that we are still lacking a full understanding of the underlying changes in soil community functioning (or the lack of) with shifts in soil biodiversity (Nielsen et al., 2011; Briones, 2014). Future studies should therefore attempt to further elucidate the relative importance of taxonomic diversity (species numbers) versus functional diversity. Effects of loss of soil biodiversity on ecosystem $\mathrm{C}$ cycling should depend on the degree of functional dissimilarity of the organisms involved (Heemsbergen et al., 2004). Hence, unraveling the level of variation in functional traits among soil organisms, both within and across feeding groups, should be a future research priority. Such studies would improve predictions on the global C cycling in the face of future environmental changes. Given the importance of the soil community in regulating the direction and magnitude of C fluxes between the atmosphere and terrestrial ecosystems, advancing our understanding of soil biodiversity impacts on biogeochemical cycles may enhance the efficacy of climate change mitigation efforts.

Author contributions. All authors contributed to conception of the idea, compilation of the data, and preparation of the manuscript. Analyses were performed by M. A. de Graaff and J. Adkins.

Acknowledgements. This work was supported by Agriculture and Food Research Initiative competitive grant no. 2012-6701020069 from the USDA National Institute of Food and Agriculture to M. A. de Graaff, and H. L. Throop's participation was supported by US National Science Foundation grants DEB-0953864 and DEB-1235828.

Edited by: K. Denef

\section{References}

Adams, D. C., Gurevitch, J., and Rosenberg, M. S.: Resampling tests for meta-analysis of ecological data, Ecology, 78, 12771283, 1997.

Andrén, O. and Balandreau, J.: Biodiversity and soil functioning from black box to can of worms?, Appl. Soil Ecol., 13, 105-108, 1999.
Araujo, P. I., Yahdjian, L., and Austin, A. T.: Do soil organisms affect aboveground litter decomposition in the semiarid Patagonian steppe, Argentina?, Oecologia, 168, 221-230, 2012.

Balvanera, P., Pfisterer, A. B., Buchmann, N., He, J. S., Nakashizuka, T., Raffaelli, D., and Schmid, B.: Quantifying the evidence for biodiversity effects on ecosystem functioning and services, Ecol. Lett., 9, 1146-1156, 2006.

Bardgett, R.: The Biology of Soil, Oxford University Press, New York, USA, 2005.

Bardgett, R., Freeman, C., and Ostle, N. J.: Microbial contributions to climate change though carbon cycle feedbacks, Int. Soc. Micro. Ecol. J., 2, 805-814, 2008.

Baxter, J. W. and Dighton, J.: Ectomycorrhizal diversity alters growth and nutrient acquisition of grey birch (Betula populifolia) seedlings in host-symbiont culture conditions, New Phytol., 152, 139-149, 2001.

Bell, T., Newman, A. J., Silverman, B. W., Turner, S. L., and Lilley, A. K.: The contribution of species richness and composition to bacterial services, Nature, 436, 1157-1160, 2005.

Bengtsson, J.: Which species? What kind of diversity? Which ecosystem function? Some problems in studies of relationships between biodiversity and ecosystem functioning, Appl. Soil Ecol., 10, 191-199, 1998.

Berg, B. and Laskowski, R.: Advances in ecological research, in: Litter decomposition: A guide to carbon and nutrient turnover, Elsevier Academic Press, San Diego, California, USA, 2006.

Bezemer, T. M., De Deyn, G. B., Bossinga, T. M., van Dam, N. M., Harvey, J. A., and Van der Putten, W. H.: Soil community composition drives aboveground plant-herbivore-parasitoid interactions, Ecol. Lett., 8, 652-661, 2005.

Bignell, D. E. and Eggleton, P.: Termites in ecosystems, in: Termites: Evolution, Sociality, Symbiosis, Ecology, edited by: Abe, T., Bignell, D. E., and Higashi, M., Kluwer Academic, Dordrecht, Netherlands, 363-387, 2000.

Bonkowski, M. and Roy, J.: Soil microbial diversity and soil functioning affect competition among grasses in experimental microcosms, Oecologia, 143, 232-240, 2005.

Borer, E. T., Seabloom, E. W., Mitchell, C. E., and Cronin, J. P.: Multiple nutrient and herbivores interact to govern diversity, productivity, composition, and infection in a successional grassland, Oikos, 123, 214-224, 2014.

Bradford, M. A., Jones, T. H., Bardgett, R. D., Black, H. I. J., Boag, B., Bonkowski, M., Cook, R., Eggers, T., Gange, A. C., Grayston, S. J., Kandeler, E., McCaig, A. E., Newington, J. E., Prosser, J. I., Setälä, H., Staddon, P. L., Tordoff, G. M., Tscherko, D., and Lawton, J. H.: Impacts of soil faunal community composition on model grassland ecosystems, Science, 298, 615-618, 2002.

Bradford, M. A., Tordoff, G. M., Black, H. I. J, Cook, R., Eggers, T., Garnett, M. H., Grayston, S. J., Hutcheson, K. A., Ineson, P., Newington, J. E., Ostle, N., Sleep, D., Stott, A., and Jones, T. H.: Carbon dynamics in a model grassland with functionally different soil communities, Funct. Ecol., 21, 690-697, 2007.

Briones, M. J. I.: Soil fauna and soil functions: a jigsaw puzzle, Front. Environ. Sci., 2, 1-22, 2014.

Cardinale, B. J., Duffy, J. E., Gonzalez, A., Hooper, D. U., Perrings, C., Venail, P., Narwani, A., Mace, G. M., Tilman, D., Wardle, D. A., Kinzig, A. P., Daily, G. C., Loreau, M., Grace, J. B., Lari- 
gauderie, A., Srivastava, D. S., and Naeem, S.: Biodiversity loss and its impact on humanity, Nature, 486, 59-67, 2012.

Carrillo, Y., Ball, B. A., Bradford, M. A., Jordan, C. F., and Molina, M.: Soil fauna alter the effects of litter composition on nitrogen cycling in a mineral soil, Soil Biol. Biochem., 43, 1440-1449, 2011.

Casper, B. B. and Jackson, R. B.: Plant competition underground, Annu. Rev. Ecol. Syst., 28, 545-570, 1997.

Clark, C. M. and Tilman, D.: Loss of plant species after chronic low-level nitrogen deposition to prairie grasslands, Nature, 451, 712-715, 2008.

Cole, L., Dromph, K. M., Boaglio, V., and Bardgett, R. D.: Effect of density and species richness of soil mesofauna on nutrient mineralisation and plant growth, Biol. Fert. Soils, 39, 337-343, 2004.

Collison, E. J., Riutta, T., and Slade, E. M.: Macrofauna assemblage composition and soil moisture interact to affect soil ecosystem functions, Acta Oecol., 47, 30-36, 2013.

Conen, F., Yakutin, M., and Sambuu, A.: Potential for detecting changes in soil organic carbon concentrations resulting from climate change, Glob. Change Biol., 9, 1515-1520, 2003.

Cong, W. F., van Ruijven, J., Mommer, L., De Deyn, G. B., Berendse, F., and Hoffland, E.: Plant species richness promotes soil carbon and nitrogen stocks in grasslands without legumes, J. Ecol., 102, 1163-1170, 2014.

Cortet, J., Joffre, R., Elmholt, S., and Krogh, P. H.: Increasing species and trophic diversity of mesofauna affects fungal biomass, mesofauna community structure and organic matter decomposition processes, Biol. Fert. Soils, 37, 302-312, 2003.

Cox, P., Wilkinson, S. P., and Anderson, J. M.: Effects of fungal inocula on the decomposition of lignin and structural polysaccharides in Pinus sylvestris litter, Biol. Fert. Soils, 33, 246-251, 2001.

Cragg, R. G. and Bardgett, R. D.: How changes in soil faunal diversity and composition within a trophic group influence decomposition processes, Soil Biol. Biochem., 33, 2073-2081, 2001.

Cramer, W., Bondeau, A., Woodward, F. I., Prentice, I. C., Betts, R. A., Brovkin, V., Cox, P.M., Fisher, V., Foley, J. A., Friend, A. D., Kucharik, C., Lomas, M. R., Ramankutty, N., Sitch, S., Smith, B., White, A., and Young-Molling, C.: Global response of terrestrial ecosystem structure and function to $\mathrm{CO}_{2}$ and climate change: results from six dynamic global vegetation models, Glob. Change Biol., 7, 357-373, 2001.

Curtis, P. S. and Wang, X. Z.: A meta-analysis of elevated CO2 effects on woody plant mass, form, and physiology, Oecologia, 113, 299-313, 1998.

de Deyn, G. B. and Van der Putten, W. H.: Linking aboveground and belowground diversity, Trends Ecol. Evol., 20, 625-633, 2005.

de Graaff, M.-A., van Groenigen, K. J., Six, J., Hungate, B., and van Kessel, C.: Interactions between plant growth and soil nutrient cycling under elevated $\mathrm{CO}_{2}$ : a Meta-Analysis, Glob. Change Biol., 12, 1-15, 2006.

De Vries, F. T., Thébault, E., Liiri, M., Birkhofer, K., Tsiafouli, M. A., Bjørnlund, L., Bracht H., Jørgensen, Brady, M. V., Christensen, S., de Ruiter, P. C., d'Hertefeldt, T., Frouzk, J., Hedlund, K., Hemerik, L., Hol, W. H. G., Hotes, S., Mortimer, S. R., Setälä, H., Sgardelis, S. P., Uteseny, K., van der Putten W. H., Wolters, V., and Bardgett, R. D.: Soil food web properties explain ecosystem services across European land use systems, Proc. Natl. Acad. Sci. USA, 110, 14296-14301, 2013.
Dilly, O., Bloem, J., Vos, A., and Munch, J. C.: Bacterial diversity in agricultural soils during litter decomposition, Appl. Environ. Microbiol., 70, 468-474, 2004.

Edsberg, E.: The quantitative influence of enchytraeids (Oligochaeta) and microarthropods on decomposition of coniferous raw humus in microcosms, Pedobiologia, 44, 132-147, 2000.

Edwards, C. A.: Soil invertebrate controls and microbial interactions in nutrient and organic matter dynamics in natural and agroecosystems, in: Invertebrates as Webmasters in Ecosystems, edited by: Coleman, D. and Hendrix, P., CAB International, Wallingford, UK, 141-159, 2000.

Eisenhauer, N. and Schädler, M.: Inconsistent impacts of decomposer diversity on the stability of aboveground and belowground ecosystem functions, Oecologia, 165, 403-415, 2011.

Eisenhauer, N., Horsch, V., Moeser, J., and Scheu, S.: Synergistic effects of microbial and animal decomposers on plant and herbivore performance, Basic Appl. Ecol., 11, 23-34, 2010.

Eisenhauer, N., Milcu, A., Sabais, A. C. W., Bessler, H., Brenner, J., Engels, C., Klarner, B., Maraun, M., Partsch, S., Roscher, C., Schonert, F., Temperton, V. M., Thomisch, K., Weigelt, A., Weisser, W. W., and Scheu, S.: Plant Diversity Surpasses Plant Functional Groups and Plant Productivity as Driver of Soil Biota in the Long Term, PLoS One. 2011 Jan 7, e16055, doi:10.1371/journal.pone.0016055.5, 2011a.

Eisenhauer, N., Sabais, A. C. W., and Scheu, S.: Collembola species composition and diversity effects on ecosystem functioning vary with plant functional group identity, Soil Biol. Biochem., 43, 1697-1704, 2011b.

Fischer J. and Lindenmayer, D. B.: Landscape modification and habitat fragmentation: A synthesis, Global Ecol. Biogeogr., 16, 265-280, 2007.

Fitter, A. H., Gilligan, C. A., Hollingworth, K., Kleczkowski, A., Twyman, R. M., Pitchford, J. W., and Programme, N. S. B.: Biodiversity and ecosystem function in soil, Funct. Ecol., 19, 369377, 2005.

Fornara, D. A. and Tilman, D., Plant functional composition influences rates of soil carbon and nitrogen accumulation, J. Ecol., 96, 314-322, 2008.

Griffiths, B. S., Ritz, K., Bardgett, R. D., Cook, R., Christensen, S., Ekelund, F., Sorensen, S. J., Baath, E., Bloem, J., de Ruiter, P. C., Dolfing, J., and Nicolardot, B.: Ecosystem response of pasture soil communities to fumigation-induced microbial diversity reductions: an examination of the biodiversity-ecosystem function relationship, Oikos, 90, 279-294, 2000.

Griffiths, B. S., Ritz, K., Wheatley, R., Kuan, H. L., Boag, B., Christensen, S., Ekelund, F., Sorensen, S. J., Muller, S., and Bloem, J.: An examination of the biodiversity-ecosystem function relationship in arable soil microbial communities, Soil Biol. Biochem., 33, 1713-1722, 2001.

Griffiths, B. S., Kuan, H. L., Ritz, K., Glover, L. A., McCaig, A. E., and Fenwick, C.: The relationship between microbial community structure and functional stability, tested experimentally in an upland pasture soil, Microb. Ecol., 47, 104-113, 2004.

Handa, I. T., Aerts, R., Berendse, F., Berg, M. P., Bruder, A., Butenschoen, O., Chauvet, E., Gessner, M. O., Jabiol, J., Makkonen, M., McKie, B. G., Malmqvist, B., Peeters, E. T. H. M., Scheu, S., Schmid, B., van Ruijven, J., Vos, V. C. A., and Hättenschwiler, 
S.: Consequences of biodiversity loss for litter decomposition across biomes, Nature, 509, 218-221, 2014.

Hanson, C. A., Allison, S. D., Bradford, M. A., Wallenstein, M. D., and Treseder, K. K.: Fungal taxa target different carbon sources in forest soil, Ecosystems, 11, 1157-1167, 2008.

Harmon, M. E., Nadelhoffer, K. J., and Blair, J. M.: Measuring decomposition, nutrient turnover, and stores in plant litter, in: Standard Soil Methods for Long-Term Ecol. Res., edited by: Robertson, G. P., Coleman, D. C., Bledsoe, C. S., and Sollins, P., Oxford University Press, New York, USA, 202-240, 1999.

Heal, O. W., Anderson, J. M., and Swift, M. J.: Plant litter quality and decomposition: an historical overview, in: Driven by Nature: plant Litter Quality and Decomposition, edited by: Cadisch, G. and Giller, K. E., CAB International, Wallingford, England, 330, 1997.

Hedges, L. V. and Olkin, I.: Statistical Methods for Meta-Analysis, Academic Press, San Diego, California, USA, 1985.

Hedlund, K. and Ohrn, M. S.: Tritrophic interactions in a soil community enhance decomposition rates, Oikos, 88, 585-591, 2000.

Heemsbergen, D. A., Berg, M. P., Loreau, M., van Haj, J. R., Faber, J. H., and Verhoef, H. A.: Biodiversity effects on soil processes explained by interspecific functional dissimilarity, Science, 306, 1019-1020, 2004.

Heneghan, L., Coleman, D. C., Zou, X., Crossley, D. A., and Haines, B. L.: Soil microarthropod contributions to decomposition dynamics: Tropical-temperate comparisons of a single substrate, Ecology, 80, 1873-1882, 1999.

Hol, W. H., De Boer, W., Termorshuizen, A. J., Meyer, K. M., Schneider, J. H. M., van Dam, N. M., van Veen, J. A., and Van Der Putten, W. H.: Reduction of rare soil microbes modifies plant-herbivore interactions, Ecol. Lett., 13, 292-301, 2010.

Holland, E. A., Robertson, G. P., Greenberg, J., Groffman, P. M., Boone, R. D., and Gosz, J. R.: Soil $\mathrm{CO}_{2}, \mathrm{~N}_{2} \mathrm{O}$, and $\mathrm{CH}_{4}$ exchange, in: Standard Soil Methods for Long-term Ecol. Res., edited by: Robertson, G. P., Bleddsoe, C. S., Coleman, D. C., and Sollins, P., Oxford University Press, New York, USA, 185201,1999.

Hooper, D. U., Bignell, D. E., Brown, V. K., Brussaard, L., Dangerfield, J. M., Wall, D. H., Wardle, D. A., Coleman, D. C., Giller, K. E., Lavelle, P., Van der Putten, W. H., De Ruiter, P. C., Rusek, J., Silver, W. L., Tiedje, J. M., and Wolters, V.: Interactions between aboveground and belowground biodiversity in terrestrial ecosystems: Patterns, mechanisms, and feedbacks, Bioscience, 50, 1049-1061, 2000.

Hooper, D. U., Adair, E. C., Cardinale, B. J., Byrnes, J. E. K., Hungate, B. A., Matulich, K. L., Gonzalez, A., Duffy, J. E., Gamfeldt, L., and O'Connor, M. I.: A global synthesis reveals biodiversity loss as a major driver of ecosystem change, Nature, 486, 105129, 2012.

Huang, C. Y., Hendrix, P. F., Fahey, T. J., Bohlen, P. J., and Groffman, P. M.: A simulation model to evaluate the impacts of invasive earthworms on soil carbon dynamics, Ecol. Model, 221, 2447-2457, doi:10.1016/j.ecolmodel.2010.06.023, 2010.

Hungate, B. A., Jackson, R. B., Field, C. B., and Chapin, F. S.: Detecting changes in soil carbon in $\mathrm{CO}_{2}$ enrichment experiments, Plant Soil, 187, 135-145, 1996.

Hungate, B. A., van Groenigen, K. J., Six, J., Jastrow, J. D., Luo, Y. Q., de Graaff, M. A., van Kessel, C., and Osenberg, C. W.: Assessing the effect of elevated carbon dioxide on soil carbon: a comparison of four meta-analyses, Glob. Change Biol., 15, 2020-2034, 2009.

Ingham, R. E., Trofymow, J. A., Ingham, E. R., and Coleman, D. C.: Interactions of bacteria, fungi and their nemotode grazers: effects on nutrient cycling and plant growth, Ecol. Monogr., 2055, 119$140,1985$.

Isbell, F., Calcagno, V., Hector, A., Connolly, J., Harpole, W. S., Reich, P. B., Scherer-Lorenzen, M., Schmid, B., Tilman, D., van Ruijven, J., Weigelt, A., Wilsey, B. J., Zavaleta, E. S., and Loreau, M.: High plant diversity is needed to maintain ecosystem services, Nature, 477, 199-U196, 2011.

Jastrow, J. D., Amonette, J. E., and Bailey, V. L.: Mechanisms controlling soil carbon turnover and their potential application for enhancing carbon sequestration, Climatic Change, 80, 5-23, 2007.

Johnson, D. W. and Curtis, P. S.: Effects of forest management on soil $\mathrm{C}$ and $\mathrm{N}$ storage: meta analysis, Forest Ecol. Manag., 140, 227-238, 2001.

Laakso, J. and Setälä, H.: Sensitivity of primary production to changes in the architecture of belowground food webs, Oikos, 87, 57-64, 1999.

Ladygina, N., Henry, F., Kant, M. R., Koller, R., Reidinger, S., Rodriguez, A., Saj, S., Sonnemann, I., Witt, C., and Wurst, S.: Additive and interactive effects of functionally dissimilar soil organisms on a grassland plant community, Soil Biol. Biochem., 42 , 2266-2275, 2010.

Lal, R.: Soil carbon sequestration to mitigate climate change, Geoderma, 123, 1-22, 2004.

LeBauer, D. S.: Litter degradation rate and beta-glucosidase activity increase with fungal diversity, Can. J. Forest Res., 40, 10761085, 2010.

Liebich, J., Schloter, M., Schaffer, A., Vereecken, H., and Burauel, P.: Degradation and humification of maize straw in soil microcosms inoculated with simple and complex microbial communities, Eur. J. Soil Sci., 58, 141-151, 2007.

Liiri, M., Setälä, H., Haimi, J., Pennanen, T., and Fritze, H.: Relationship between soil microarthropod species diversity and plant growth does not change when the system is disturbed, Oikos, 96, 137-149, 2002.

Mack, M. C., Schuur, E. A. G., Bret-Harte, M. S., Shaver, G. R., and Chapin III, F. S.: Ecosystem carbon storage in Arctic tundra reduced by long-term nutrient fertilization, Nature, 431, 440-443, 2004.

Magurran, A. E.: Species abundance distributions: pattern or process? Funct. Ecol., 19, 177-181, 2005.

Maherali, H. and Klironomos, J. N.: Influence of phylogeny on fungal community assembly and ecosystem functioning, Science, 316, 1746-1748, 2007.

Maron, J. L., Marlet, M., Klironomos, J. N., and Cleveland, C. C.: Soil fungal pathogens and the relationship between plant diversity and productivity, Ecol. Lett., 14, 36-41, 2011.

McKane, R. B., Grigal, D. F., and Russelle, M. P.: Spatiotemporal differences in N-15 uptake and the organization of an old-field plant community, Ecology, 71, 1126-1132, 1990.

Mikola, J. and Setälä, H.: Productivity and trophic-level biomasses in a microbial-based soil food web, Oikos, 82, 158-168, 1998a.

Mikola, J. and Setälä, H.: Relating species diversity to ecosystem functioning: mechanistic backgrounds and experimental approach with a decomposer food web, Oikos, 83, 180-194, 1998b. 
Milcu, A. and Manning, P.: All size classes of soil fauna and litter quality control the acceleration of litter decay in its home environment, Oikos, 120, 1366-1370, 2011.

Milcu, A., Partsch, S., Scherber, C., Weisser, W. W., and Scheu, S.: Earthworms and legumes control litter decomposition in a plant diversity gradient, Ecology, 89, 1872-1882, 2008.

Millennium Ecosystem Assessment (MEA), Ecosystems and Human Well-being: Synthesis, available at: www. millenniumassessment.org/documents/document.356.aspx.pdf (last access: 25 June 2014), 2006.

Nielsen, U. N., Ayres, E., Wall, D. H., and Bardgett, R. D.: Soil biodiversity and carbon cycling: a review and synthesis of studies examining diversity-function relationships, Eur. J. Soil Sci., 62, 105-116, 2011.

Orwin, K. H., Wardle, D. A., and Greenfield, L. G.: Ecological consequences of carbon substrate identity and diversity in a laboratory study, Ecology, 87, 580-593, 2006.

Peters, R. H.: The Ecological Implications of Body Size, Cambridge University Press, Cambridge, UK, 1983.

Petersen, H. and Luxton, M.: A comparative-analysis of soil fauna populations and their role in decomposition processes, Oikos, 39, 287-388, 1982.

Phoenix, G. K., Hicks W. K., Cinderby, S., Kuylenstierna, J. C. I. Stock, W. D., Dentener, F. J., Giller, K. E., Austin, A. T., Lefroy, R. D. B., Gimeno, B. S., Ashmore, M. R., and Ineson, P.: Atmospheric nitrogen deposition in world biodiversity hotspots: the need for a greater global perspective in assessing $\mathrm{N}$ deposition impacts, Glob. Change Biol., 12, 470-476, 2006.

Progar, R. A., Schowalter, T. D., Freitag, C. M., and Morrell, J. J.: Respiration from coarse woody debris as affected by moisture and saprotroph functional diversity in Western Oregon, Oecologia, 124, 426-431, 2000.

Prosser, J. I. and Nicol, G. W.: Archaeal and bacterial ammonia oxidisers in soil: the quest for niche specialisation and differentiation, Trends Microbiol., 20, 523-531, 2012.

Reich, P. B., Tilman, D., Isbell, F., Mueller, K., Hobbie, S. E., Flynn, D. F. B., and Eisenhauer, N.: Impacts of biodiversity loss escalate through time as redundancy fades, Science, 336, 589-592, 2012.

Risch, A. C., Haynes, A. G., Busse, M. D., Filli, F., and Schutz, M.: The Response of Soil $\mathrm{CO}_{2}$ Fluxes to Progressively Excluding Vertebrate and Invertebrate Herbivores Depends on Ecosystem Type, Ecosystems, 16, 1192-1202, 2013.

Roesch, L. F., Fulthorpe, R. R., Riva, A., Casella, G., Hadwin, A. K. M., Kent, A. D., Daroub, S. H., Camargo, F. A. O., Farmerie, W. G., and Triplett, E. W.: Pyrosequencing enumerates and contrasts soil microbial diversity, Int. Soc. Micro. Ecol. J., 1, 283-290, 2007.

Rosenberg, M. S., Adams, D. C., and Gurevitch, J.: MetaWin: Statistical Software for Meta-Analysis, Version 2.0, Sinauer Associates, Sunderland, Massachussettes, USA, 2000.

Sanderson, E. W., Jaiteh, M., Levy, M. A., Redford, K. H., Wannebo, A. V., and Woolmer, G.: The human footprint and the last of the wild, Bioscience, 52, 891-904, 2002.

Schenk, H. J., Callaway, R. M., and Mahall, B. E.: Spatial root segregation: Are plants territorial?, Adv. Ecol. Res., 28, 145-180, 1999.

Scherber, C., Eisenhauer, N., Weisser, W. W., Schmid, B., Voigt, W., Fischer, M., Schulze, E.D., Roscher, C., Weigelt, A., Allan, E., Bessler, H., Bonkowski, M., Buchmann, N., Buscot, F., Clement,
L. W., Ebeling, A., Engels, C., Halle, S., Kertscher, I., Klein, A. M., Koller, R., Konig, S., Kowalski, E., Kummer, V., Kuu, A., Lange, M., Lauterbach, D., Middelhoff, C., Migunova, V. D., Milcu, A., Muller, R., Partsch, S., Petermann, J. S., Renker, C., Rottstock, T., Sabais, A., Sechi, V., D’Annibale, A., Ambus, P., Sárossy, Z., Krogh, P. H., Eriksen, J., and Holmstrup, M.: Collembola feeding habits and niche specialization in agricultural grasslands of different composition, Soil Biol. Biochem., 74, 3138, doi:10.1016/j.soilbio.2014.02.019, 2014.

Scheu, S., Schlitt, N., Tiunov, A. V., Newington, J. E., and Jones, T. H.: Effects of the presence and community composition of earthworms on microbial community functioning, Oecologia, 133, 254-260, 2002.

Setälä, H.: Sensitivity of ecosystem functioning to changes in trophic structure, functional group composition and species diversity in belowground food webs, Ecol. Res., 17, 207-215, 2002.

Setälä, H. and Huhta, V.: Soil fauna increase Betula pendula growth: laboratory experiments with coniferous forest floor, Ecology, 72, 665-671, 1991.

Setälä, H. and McLean, M. A.: Decomposition rate of organic substrates in relation to the species diversity of soil saprophytic fungi, Oecologia, 139, 98-107, 2004.

Setälä, H., Berg, M. P., and Jones, T. H.: Trophic structure and functional redundancy in soil communities, in: Biological diversity and function in soils, edited by: Bardgett, R. D., Hopkins, D. W., and Usher, M. B., Cambridge University Press, 236-249, 2005.

Six, J., Conant, R. T., Paul, E. A., and Paustian, K.: Stabilization mechanisms of soil organic matter: Implications for C-saturation of soils, Plant Soil, 241, 155-176, 2002.

Slade, E. M. and Riutta, T.: Interacting effects of leaf litter species and macrofauna on decomposition in different litter environments, Basic Appl. Ecol., 13, 423-431, 2012.

Smith, P.: How long before a change in soil organic carbon can be detected? Glob. Change Biol., 10, 1878-1883, 2004.

Steinbeiss, S., Bessler, H., Engels, C., Temperton, V. M., Buchmann, N., Roscher, C., Kreutziger, Y., Baade, J., Habekost, M., and Gleixner, G.: Plant diversity positively affects short-term soil carbon storage in experimental grasslands, Glob. Change Biol., 14, 2937-2949, 2008.

Stevens, C. J.: Impact of nitrogen deposition on the species richness of grasslands, Science, 303, 1876-1879, 2004.

Sulkava, P., Huhta, V., Laakso, J., and Gylen, E. R.: Influence of soil fauna and habitat patchiness on plant (Betula pendula) growth and carbon dynamics in a microcosm experiment, Oecologia, 129, 133-138, 2001.

Szlavecz, K., McCormick, M., Xia, L. J., Saunders, J., Morcol, T., Whigham, Filley, D. T., and Csuzdi, C.: Ecosystem effects of non-native earthworms in Mid-Atlantic deciduous forests, Biol. Invasions, 13, 1165-1182, 2011.

Tilman, D., Wedin, D., and Knops, J.: Productivity and sustainability influenced by biodiversity in grassland ecosystems, Nature, 379, 718-720, 1996.

Tilman, D., Hill, J., and Lehman, C.: Carbon-negative biofuels from low-input high-diversity grassland biomass, Science, 314, 15981600, 2006.

Tiunov, A. V. and Scheu, S.: Facilitative interactions rather than resource partitioning drive diversity-functioning relationships in laboratory fungal communities, Ecol. Lett., 8, 618-625, 2005. 
Toljander, Y. K., Lindahl, B. D., Holmer, L., and Hogberg, N. O. S.: Environmental fluctuations facilitate species co-existence and increase decomposition in communities of wood decay fungi, Oecologia, 148, 625-631, 2006.

van der Heijden, M. G. A., Klironomos, J. N., Ursic, M., Moutoglis, P., Streitwolf-Engel, R., Boller, T., Wiemken, A., and Sanders, I. R.: Mycorrhizal fungal diversity determines plant biodiversity, ecosystem variability and productivity, Nature, 396, 69-72, 1998.

van der Heijden, M. G. A., Wiemken, A., and Sanders, I. R.: Different arbuscular mycorrhizal fungi alter coexistence and resource distribution between co-occurring plant, New Phytol., 157, 569578, 2003.

van der Heijden, M. G. A., Bardgett, R. D., and van Straalen, N. M.: The unseen majority: soil microbes as drivers of plant diversity and productivity in terrestrial ecosystems, Ecol. Lett., 11, 296310, 2008.

van Groenigen, K. J., Six, J., Hungate, B., de Graaff, M.-A., van Breemen, N., and van Kessel, C.: Element interactions limit soil carbon storage, Pro. Natl. Aca. Sci., 103, 6571-6574, 2006.

van Ruijven, J. and Berendse, F.: Diversity-productivity relationships: Initial effects, long-term patterns, and underlying mechanisms, Proc. Natl. Acad. Sci. USA, 102, 695-700, 2005.

Vitousek, P. M. and Mooney, H. A.: Human domination of earth's ecosystems, Science, 277, 494-499, doi:10.1126/science.277.5325.494, 1997.

Wagg, C., Bender, S. F., Widmer, F., and van der Heijden, M. G. A.: Soil biodiversity and soil community composition determine ecosystem multifunctionalityl, Proc. Natl. Acad. Sci. USA, 111, 5266-5270, 2014.

Wall, D. H., Bradford, M. A., St John, M. G., Trofymow, J. A., Behan-Pelletier, V., Bignell, D. D. E., Dangerfield, J. M., Parton, W. J., Rusek, J., Voigt, W., Wolters, V., Gardel, H. Z., Ayuke, F. O., Bashford, R., Beljakova, O. I., Bohlen, P. J., Brauman, A., Flemming, S., Henschel, J. R., Johnson, D. L., Jones, T. H., Kovarova, M., Kranabetter, J. M., Kutny, L., Lin, K. C., Maryati, M., Masse, D., Pokarzhevskii, A., Rahman, H., Sabara, M. G., Salamon, J. A., Swift, M. J., Varela, A., Vasconcelos, H. L., White, D., and Zou, X. M.: Global decomposition experiment shows soil animal impacts on decomposition are climate-dependent, Glob. Change Biol., 14, 2661-2677, 2008.

Wall, D. H., Bardgett, R. D., and Kelly, E. F.: Biodiversity in the dark, Nat. Geosci., 3, 297-298, 2010.
Wardle, D. A.: Is "sampling effect" a problem for experiments investigating biodiversity-ecosystem function relationships?, Oikos, 87, 403-407, 1999.

Wardle, D. A., Bonner, K. I., Barker, G. M., Yeates, G. W., Nicholson, K. S., Bardgett, R. D., Watson, R. N., and Ghani, A.: Plant removals in perennial grassland: Vegetation dynamics, decomposers, soil biodiversity, and ecosystem properties, Ecol. Monogr., 69, 535-568, 1999.

Wardle, D. A., Bardgett, R. D., Klironomos, J. N., Setälä, H., van der Putten, W. H., and Wall, D. H.: Ecological linkages between aboveground and belowground biota, Science, 304, 1629-1633, 2004.

Wardle, D. A., Bardgett, R. D., Callaway, R. M., and Van der Putten, W. H.: Terrestrial Ecosystem Responses to Species Gains and Losses, Science, 332, 1273-1277, 2011.

Warren, R. J. and Bradford, M. A.: Ant colonization and coarse woody debris decomposition in temperate forests, Insect. Soc., 59, 215-221, 2012.

Wertz, S., Degrange, V., Prosser, J. I., Poly, F., Commeaux, C., Freitag, T., Guillaumaud, N., and Le Roux, X.: Maintenance of soil functioning following erosion of microbial diversity, Environ. Microbiol., 8, 2162-2169, 2006.

Wilkinson, A., Solan, M., Taylor, A. F. S., Alexander, I. J., and Johnson, D.: Intraspecific Diversity Regulates Fungal Productivity and Respiration, Plos One, 5, doi:10.1371/journal.pone.0012604 2010.

Wilkinson, A., Alexander, I. J., and Johnson, D.: Species richness of ectomycorrhizal hyphal necromass increases soil CO2 efflux under laboratory conditions, Soil Biol. Biochem., 43, 1350-1355, 2011.

Wilkinson, A., Solan, M., Alexander, I., and Johnson, D.: Species richness and nitrogen supply regulate the productivity and respiration of ectomycorrhizal fungi in pure culture, Fungal Ecol., 5, 211-222, 2012.

Yang, X. D. and Chen, J.: Plant litter quality influences the contribution of soil fauna to litter decomposition in humid tropical forests, southwestern China, Soil Biol. Biochem., 41, 910-918, 2009.

Zimmer, M., Kautz, G., and Topp, W.: Do woodlice and earthworms interact synergistically in leaf litter decomposition?, Funct. Ecol., 19, 7-16, 2005. 